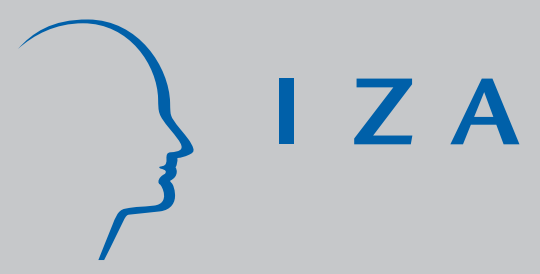

IZADP No. 4033

\title{
Understanding the Labour Market for Older Workers: A Survey
}

John S. Heywood

W. Stanley Siebert

February 2009 


\title{
Understanding the Labour Market for Older Workers: A Survey
}

\author{
John S. Heywood \\ University of Wisconsin-Milwaukee \\ W. Stanley Siebert \\ University of Birmingham \\ and IZA
}
Discussion Paper No. 4033
February 2009

\author{
IZA \\ P.O. Box 7240 \\ 53072 Bonn \\ Germany \\ Phone: +49-228-3894-0 \\ Fax: +49-228-3894-180 \\ E-mail: iza@iza.org
}

\begin{abstract}
Any opinions expressed here are those of the author(s) and not those of IZA. Research published in this series may include views on policy, but the institute itself takes no institutional policy positions.

The Institute for the Study of Labor (IZA) in Bonn is a local and virtual international research center and a place of communication between science, politics and business. IZA is an independent nonprofit organization supported by Deutsche Post Foundation. The center is associated with the University of Bonn and offers a stimulating research environment through its international network, workshops and conferences, data service, project support, research visits and doctoral program. IZA engages in (i) original and internationally competitive research in all fields of labor economics, (ii) development of policy concepts, and (iii) dissemination of research results and concepts to the interested public.
\end{abstract}

IZA Discussion Papers often represent preliminary work and are circulated to encourage discussion. Citation of such a paper should account for its provisional character. A revised version may be available directly from the author. 
IZA Discussion Paper No. 4033

February 2009

\begin{abstract}

\section{Understanding the Labour Market for Older Workers: A Survey}

The paper asks why retirement can be so abrupt in countries such as France $(1 / 2 \%$ of the workforce over 65), yet staged in Japan (8\% over 65). We find part of the answer in tax laws that prevent people working and receiving a pension, and make little allowance for fair pension increases if retirement is deferred. While these laws have begun to change, we find another part of the answer in employment protection laws. These laws coupled with inflexible collectively agreed wages make employers choosy about hiring the old. The advent of "age discrimination" law reinforces employment protection and may well reduce older workers' hiring opportunities especially where wages are rigid.
\end{abstract}

JEL Classification: $\quad 138, \mathrm{J32}, \mathrm{J} 71$

Keywords: mandatory retirement, deferred pay, age discrimination, older workers

Corresponding author:

W. S. Siebert

Birmingham Business School

University House

Edgbaston

Birmingham B15 2TT

United Kingdom

E-mail:w.s.siebert@bham.ac.uk 


\title{
Understanding the Labour Market for Older Workers - a Survey ${ }^{1}$
}

\begin{abstract}
Hundreds of workers who want to work beyond the age of 65 were dealt a blow yesterday after campaigners lost an important round in their legal battle to banish Britain's compulsory retirement age. Help the Aged ...said: "Allowing companies to show loyal workers the door just because they are 65 or over makes a mockery of age discrimination laws which are there to make clear that age is just a number, not an indicator of your competency". (The Times, 24/9/08)
\end{abstract}

\section{Introduction}

Why is retirement so abrupt? Does it make sense for it to be, and if not, what can we do about it? Are the UK's new Employment Equality (Age) Regulations (UK 2006), which attempt to reduce "age discrimination", likely to help the functioning of the market for older workers? These are important questions, because retirement affects the working lives and happiness of so many people. About 3 million men and women move out of the workforce between the ages of 55 and 70 each year in the UK. This means that about half the productive capacity of this group is unused (Gruber and Wise 1999: 70). Things could be different - in Japan, the unused capacity figure is only $20 \%$.

Normally we would expect a gradual transition from long hours to shorter and shorter hours. Indeed, happiness studies (Winkelman et al, 1998) indicate those individuals "out of the labourforce" are less happy, and would have presumably preferred such a transition. Survey evidence confirms this with fully $1 / 3$ of those aged 50 to 70 years claiming they would postpone full retirement if offered a phased retirement (Watson Wyatt Worldwide 2004). Meadows (2003: 39) gives further survey evidence from a range of countries including the US, UK, France, Germany and Scandinavia that older workers are more likely to experience redundancy and hence involuntary early retirement - perhaps as a result of "collusion" between unions, employers and the state to massage unemployment statistics. A recent survey shows that $59 \%$ of over 50s would like to work beyond the statutory pension age (OECD 2004: 103). Delsen (1996) talks of "pension shock", and joins many in calling for a "staged" retirement. Moreover, in Japan we do in fact see something like a gradual transition for many "retirees". Therefore, a gradual transition is possible, and many retired desire it. The fact that we do not observe such a transition reflects in part the constraint imposed on individuals by pension rules such as the mandatory retirement mentioned in the opening quotation. Mandatory retirement is not permitted in the US, which is said to have the "symbolic effect" (Gendell 2008: 52) of indicating "the propriety of continuing to work".To ask a further question, then, should we have these rules?

\footnotetext{
${ }^{1}$ We acknowledge comments from Phillip Booth and Deborah Cooper, and are also grateful to the Institute of Economic Affairs for financial support, none of whom bears responsibility for the outcome.
} 
In fact, it may be the employment protection rules of age discrimination legislation, rather than mandatory retirement that are problematic for older workers wishing to continue. We discuss mandatory retirement and its link with efficient long-term contracts in detail below. But the fact that the USA has had no mandatory retirement since 1986, while Japan permits it and has a higher participation of older workers would seem to indicate that mandatory retirement is not central. On the other hand, employment protection legislation (EPL) could be central because, in general, raising the firing costs of workers is likely to make firms averse to the risk of hiring older workers (Daniel and Siebert 2005). Therefore, age discrimination law which specifically protects the job rights of older workers could make firms even less likely to hire them (Lahey, 2006).

Our plan is as follows. First, we set the scene by looking at older worker employment patterns in the UK and other countries, and also over time. Next, we consider the basic economics of retirement using the conventional supply and demand framework. Then in the third section, we add policy determinants such as the UK's new age discrimination law to the supply and demand analysis, and draw together some answers to our initial questions.

\section{The Facts}

Figure 1 shows the abrupt movement out of work for individuals in their 60 s. Over a ten year span, for men aged in their late 50s (55-59) to late 60s (65-74), participation falls from around $80 \%$ to only $10 \%$. Initially, as can be seen from the high disability proportions, many of this group "retire" by gaining access to the disability rolls. Disability, in fact, has become the UK's form of early retirement, since (OECD, 2006: 96-97) medical assessment procedures are loose and there is no requirement to actively seek work. For many, this state is a form of concealed unemployment (actual unemployment is quite low), perhaps in response to older workers' difficulties in being hired, which we treat later. Then they increasingly move into retirement proper at age 65, once eligible to receive the state retirement pension. Women's movement out of work is nearly as precipitous, occurring earlier because their state pension age is 60 . By age 75 , a mere $1-2 \%$ of the population is working.

Figures 2 and 3 show what a "staged" retirement means for the men and women that achieve it. Looking at men first in Figure 2, we see that self-employment and part-time employment come to dominate with age. The picture for the main under-55 group is given in the first column, with $14 \%$ self-employed (coloured white), and hardly any part-time work. However, this picture completely changes for those still at work past 65 . Here, we see that self-employment is the main category (42\%), and of the rest, full-time work takes second place to part-time. Women in Figure 3 show similar trends, except that full-time work more or less disappears for the over-65s.

Figures 2 and 3 illustrate the nub of the disincentive for the older worker in the UK approaching eligibility for a pension: company/occupational pensions have not, in the past, easily been combined with regular work for the same employer (though since 2006 there have been improvements - below). Admittedly, the state pension can be so combined, but nearly 50\% of pensioners (FRS 2006: Table 3.28) also have a company pension, and are thus subject to the disincentive. Scheme rules have generally stated that if the worker wants to combine working with a pension, he/she has to change jobs. Moreover, if a worker has 
decided to defer the pension, and so continue to work on, the adjustment to the pension value has not generally been actuarially fair, so the worker has lost by working on. The UK has not been unusual in having this type of rule, which has applied for example both in the USA (Penner et al, 2002) and in France (Blanchet and Pele 1999: 116). Self-employed workers are not affected by the company pension rules, since they run their own scheme, which explains why they remain longer in work in Figures 2 and 3. Moreover, some workers are able to begin self-employment as a contractor with their previous firm but the rules governing such a transition are very limiting in the US and UK even as continuing a post-retirement relationship with a former employer is encouraged in Japan.

Older workers, in general, have a more difficult time in changing jobs than young (Hurd, 1996) because jobs have hiring and training fixed costs which employers will be reluctant to incur for older workers who necessarily will spend a shorter time with the firm. These factors, in part, underlie the tendency for employers to hire mainly young workers even though they employ old workers - which we discuss more below. Hence, unemployment duration is longer for older workers. Then, when workers become eligible for a pension, they naturally want to work fewer hours anyway (an income effect). They face a thin job market, so it is little wonder that most retire. For those that continue on, often only poorly paid secondary jobs remain as we see from the tendency for part-time work to increase with age.

Country comparisons are instructive. We can relate differences in the participation of older workers to differences in country pension systems and other factors such as union wage setting and EPL. Figure 4 compares participation of older male workers in France, the UK, the US and Japan (the picture for females is similar). As can be seen, Japan is the clear leader, with $8 \%$ of its workforce made up of men over 65 , which is almost a $50 \%$ labourforce participation rate. France takes the duck's prize, with only $1 / 2 \%$. France even has hardly any men 60-64 working. The UK and the US come in the middle, with the UK doing quite well for the 60-64 group, and the US doing better with the over $65 \mathrm{~s}$.

Several points can be made concerning Japan's success. To start with, Japan has no age discrimination law, and mandatory retirement is the norm at age 60 or earlier (Seike 1997). Companies make large lump-sum severance payments, up to the value of four year's salary, to ensure that employees leave at the end of their "lifetime employment". Workers in their late 50s are therefore confronted, as they would be in other countries, with finding a new job. However, search is made easier by the fact that strict Japanese EPL only applies to regular work, not to temporary jobs (OECD 2004: 72). Thus, it is common for workers to retire at 60 but immediately sign a series of short-term temporary contracts with their original employer. Early retirement with a reduced pension is available at age 60, but high earning workers do not qualify, and even low earners have a 20\% reduction (Yashiro and Oshio 1999: 252). Individuals who continue to work until the state pension age of 65 then collect the pension which is paid irrespective of whether they are working or not, and so does not affect the retirement decision. Hence, the implicit tax on continued work after age 65 is low in Japan at around 10\% (Duval 2003: 40). 
In France, by contrast, the state pension has in the past (the 2003 pension reform removes some restrictions - OECD 2005, 2008 ) considerably affected the retirement decision, because individuals have not been able to receive it without stopping work for their current employer (Blanchet and Pele 1999: 122). Moreover, if a worker has decided to continue on working, there has been no actuarially fair increment to the pension - though this situation may be improving. Consequently, the implicit tax on continued work has been high, about 70\% (Duval 2003: 40). Another point of difference with Japan is France's well developed early retirement schemes (Blanchet and Pele 1999: 117, OECD 2005: 77), initially developed in the 1960s to reduce unemployment, and expanded in the 1980s to cover onequarter of the 60-64 group. Indeed, laid-off workers as young as 57 have been able to gain full unemployment insurance payments until they reach the age to take a normal pension. Taking these early retirement schemes into account (Duval 2003: Figure 7B) gives an implicit tax on work for the 55-59 group in France of 60\%, compared to about 25\% for the UK (which has the disability route - Figure 1), and a negligible rate in Japan. A final point is that the strictness of EPL in France bears heavily on older workers via the "Delalande contribution" (OECD 2005: 109) which subjects firms to a penalty of up to a year's pay if they dismiss a worker over 50 . Such strictness reduces firms' willingness to employ older workers (this tendency is admitted, and the contribution is due to be phased out - OECD 2008), and probably accounts for the pressures to expand the retirement schemes in the first place.

Figures 5 and 6 give more detail on the France-UK comparison. Figure 5 presents trends over the past 25 years, and we see that UK shares for both 60-64 and 65+ age groups have more or less held their own, with the $65+$ group actually increasing a little. In France, by contrast, the shares of both groups have been gone from bad to worse. Interestingly, even over the past 10 years, while there have been good UK improvements in both male and particularly female 55-64 participation rates (as Schirle 2008 emphasises), the trend in France has remained downward.

Figure 6 compares the fortunes of another outsider group, young workers (15-24), with older workers. Here, we express changes 1980-2005 in the workforce share of both of these groups relative to prime age workers (the same calculation is made in Bertola et al. 2007). Thus, we see that over the past 25 years, the UK has experienced deterioration in the position of young workers, but older workers have more or less held their own. In contrast, French prime age workers have increased their labourforce share by about $50 \%$ relative to young workers, and by a drastic $100 \%$ relative to old. This figure underlines how badly the French labour market performs for older workers.

Finally, Figure 7 shows trends for the US. We see that labourforce participation rates have risen for both the pre-retirement 60-64 group, and the "retirement" 65+ group. (For simplicity, only males are shown, but the trends are similar for women.) These trends are somewhat better than those for the UK (Figure 5). Moreover, the share of full-time workers has increased at all older ages in the US. Changes in the nature of social security seem important in accounting for these trends.

Let us consider the changes for the 60-64 and 65+ groups in turn. For the 60-64 age 
group, early retirement has become more costly because of the change toward defined contribution private pensions (away from defined benefit) and the increasing costs of health insurance (Medicare begins no earlier than age 65). For the 65+ group, first, there has been the increase in the normal retirement age under social security from 65 to 66 in the years previous to 2008. Moreover, it will increase further reaching 67 for those born after 1960 . Second, the elimination of the earnings test (which reduced benefits by 1 dollar for every 3 dollars earned above a modest limit) for beneficiaries at or above the normal retirement age increased the incentive of those drawing a pension to remain working. This test remains in place for those taking early retirement, further discouraging the taking of early retirement. Third, actuarial changes in social security have increased the benefits of delayed retirement up to age 70 .

A further important factor working in the opposite direction appears to have been age discrimination law. While the US laws forbid mandatory retirement, they also increase the firing costs of older workers with the usual EPL result that employers become reluctant to hire the protected group in the first place. There are admittedly conflicting results here. Neumark and Stock (1999) find that state-level age discrimination laws increase the employment of old people - perhaps by reducing dismissals. On the other hand, Lahey (2006) finds that state age discrimination laws result in fewer older workers being hired, and in an increase in the proportion opting for retirement. We will discuss the results in more detail below, suffice it to say here that strengthening of job rights for the older employed may come at a cost to outsiders (see also Adams 2004).

\section{The Economic Underpinnings}

Let us now consider in more detail the economic underpinnings. Table 1 categorises the major forces operating under supply-side and demand-side headings. This table examines basic free market forces that we assume are always operative. Table 3, considered later, will take up forces that are susceptible to policy, the laws affecting taxes, or union power, and of course age discrimination law. We will work through Table 1's entries in turn, starting with the supply-side.

Starting with health problems, these are a constant, likely to be broadly similar across countries, and over time. Of course, individual health problems are clearly an important contributor to retirement and early retirement. The recent paper by Schirle (2008) shows that educated men 55-64 are more likely to be in the workforce - perhaps because their health is better. UK data (Disney 1996: 213) show poor health as being the main self-assessed reason for retirement for about half of men under 60, and one-third of women. UK retirees assign this reason more importance than financial inducement (the pension), or job finding difficulties. Admittedly, there seem to be considerable differences among countries (Disney 1996: 216), with health being less important relative to other personal reasons in France, for example. Also Blau and Shvydko (2007: Table 1) show that while $30 \%$ of individuals aged $50+$ whose health turns from "good" to "bad" withdraw completely from the labour market, so do $15 \%$ of individuals whose health remains good. Clearly, bad health is by no means the whole story when examining the determinants of retirement. Moreover, while an individual's 
health declines with age, the decline is generally gradual, not abrupt. Hence, health problems cannot account for the abrupt transition to retirement, nor for the large differences among countries that we observe.

Many of the same points can be made about increasing tastes for leisure. .It is common to accept (e.g., Blau and Shvydka 2007) that as workers age they acquire a greater taste for leisure. Of course, tastes are observed with difficulty. Zabalza et al's (1980) classic early paper found age per se to be a strong determinant of retirement, holding constant health and many other factors including the pension that would be lost if the individual continued to work. The authors (1980: 259) then assume that this result shows the force of changing tastes, changes which are themselves determined by "sociological" factors, which are of course vague. Gendell (2008: 52) believes, for example that the abolition of mandatory retirement in the US has a symbolic effect and confirms "the propriety of continuing to work" - the law thereby modifying tastes. This reasoning sounds plausible, but points rather to the law on mandatory retirement (below) than tastes. Again, the higher proportion of old people in Japan (Yoshiro and Oshiro 1999) who live with their children might be a sociological factor that determines tastes. Nevertheless, claiming that differences across countries flow from different tastes for leisure among the old provides no guidance what causes those taste differences and seems something of a cop-out. Taste explains everything and nothing.

Older workers also seemingly have less desire, or ability, to adapt to new methods of work, our third entry. Certainly older workers are far less likely to work in those positions and firms that use the latest technological innovations (Aubert et al. 2006). Such a pattern might follow from their shorter investment horizons, and is perhaps also linked to apparent changes in tastes just discussed. Older workers do receive less training as measured in surveys such as the European Labourforce Surveys. For example, of UK workers 50+ (2549) $9.5 \%(18.9 \%)$ had "received some education or training in the previous month" (Funk 2004: 31). OECD data (2006: 75) show this difference to be true for all the OECD countries they consider (unfortunately omitting Japan). At the same time, O'Mahony and Peng (2008: 18) make the interesting finding that many workers reject training offers, and that the rate of rejection is much higher among older workers, reaching $80 \%$ for the unskilled group.

Older workers, then, might seem to be "powering down" and preparing for retirement. However, we must remember that such powering down and lack of adaptability itself might be a response to imperfections in the old age labour market. The OECD (2006: 75) finds that countries with a high average retirement age also have a high rate of training of old relative to young workers. In other words, lack of adaptability may not really be causal. Older workers that know they do not face mandatory retirement and imagine a longer period of phased retirement will have longer investment horizons and be more likely to engage in training and make adaptations. The trail thus returns to what limits phased retirement.

Let us turn next to fixed costs, the first entry on the demand-side. Hurd (1996) gives a comprehensive treatment of the fixed costs problem for older workers. When firms hire, they must incur costs both when hiring/selecting workers to fill jobs, and also when training the workers. These costs are per head, and make workers on part-time hours more expensive 
since the costs can be spread over fewer hours. Hurd (1996: 26) also adds company health insurance premiums to worker fixed costs, since insurance companies charge premiums on a per worker rather than per hour basis (an ill worker's claim, whether part- or full-time, is just as costly). He derives an average figure for fixed costs of $25 \%$ of full-time total labour costs, and this percentage would of course be higher for older workers because of the health element.

If older workers wish to phase their retirement, and move into part-time work, they must accept a large reduction in pay to allow for the job's fixed costs. While this reduction in earnings may be prohibited by the anti-discrimination rules, we note, more generally, that if wages are inflexible, few new part-time openings will be available. It might be worth noting in this context that part-time work opportunities are low in France, but high in Japan. (Yet part-time work is just as low in the US as in France, which undermines a simple linkage between availability of part-time, and better participation of older workers.) Then, the problem of fixed costs could explain why pay in part-time jobs is so low, putting off older workers, and thereby explaining the abruptness of the retirement transition. If, additionally, we invoke wage inflexibility (see policy factors below), few part-time jobs will be offered in any case, making an even more abrupt transition - and helping explain the country differences we observe.

The teamwork problem, the next entry, has much in common with fixed costs. If production is organised in teams, a premium is placed on being there with the team (on working time arrangements, see also OECD 2006: 79). Part-time and flexi-time jobs then carry a pay penalty. They are also generally low skilled (Delsen, 1996), and retirees who want to reduce their hours cannot do so in a career job. Building on the teamwork problem, Blau and Shvydko (2007) present a model in which employers have either a rigid or a flexible technology. The rigid technology is associated with team production and the need to have full time workers always present, while the flexible technology allows older workers to reduce hours of work. They argue that the share of older workers in a firm is actually a measure of how flexible that firm's technology is. Backing this view, they find evidence that these "flexible" firms are indeed more attractive to older workers, who are less likely to leave such firms than the inflexible ones. Thus, provided that we accept that many older workers wish, for some reason, to reduce their working hours as they age, both fixed cost and teamwork forces evidently help us explain why the market for older workers differs from that for younger.

The third entry in the demand-side column concerns implicit contracts: efficient longterm contracts involving deferred pay which are important for our inquiry. Lazear's (1979) famous paper models a workplace in which fear of losing deferred pay deters worker shirking, increases productivity and generates long-term employment relationships. Older workers earn more than their marginal product (with the company pension as final payoff), while young workers earn less. In this view the firm does not hire older workers because their shorter employment horizon means they are less well motivated by delayed compensation. ${ }^{2}$ Such deferred pay contracts ("Lazear contracts") are risky for workers in that

\footnotetext{
${ }^{2}$ Goldin (1986) claims, similarly, that women are less well motivated by delayed compensation because of their lower expected tenure.
} 
the firm has an incentive to cheat and unfairly dismiss the worker later in the contract to save on the deferred pay and the pension. If workers believe that the firm may renege on the agreement, pay levels at the end of the contract must more than offset the period of low pay when a junior to compensate for the risk - "bonding is not costless" (Hutchens 1986: 443).

Thus, deferring pay creates fixed contracting costs and generates an incentive (similar to hiring/training costs) to hire younger workers who have more years to spread the costs over. Such contracts might then underlie the fact (Hutchens 1986) that so few firms hire older workers - even while employing older workers (and binding them to stay, as in the Japanesestyle lifetime employment). The suggestion that firms do not give equal chances to old and young workers in hiring of course flies directly in the face of age discrimination law. Moreover, since deferred pay will necessarily be higher than marginal productivity later in the contract a definite retirement date is required, otherwise the firm will lose. Thus, deferred pay incentive schemes explain the emphasis that firms place on mandatory retirement as well.

Table 2 gives the results of several studies in various countries which support the predictions that deferred pay contracts gives older workers less chance of being hired, and needs with mandatory retirement. In particular, Hutchen's (1986) famous early study found that an "opportunity index" of older worker hiring was higher in occupations and industries in which pensions, mandatory retirement and tenure were lower. These results are confirmed in other US studies as can be seen. Daniel and Heywood (2007) have performed a similar analysis for the UK. They find that firms with pension provision, more steeply increasing wages, and with more internal recruitment (hence longer tenure, as expected with deferred pay) are less likely to hire older workers. Similar findings have been reported for Australia, Germany and Hong Kong (the Appendix gives more detail).

The final demand-side free market force given in Table 1 is specific training. The need for specific training disadvantages older workers simply via the usual fixed cost argument (Oi, 1962), that the costs of training can be spread over a longer period for young workers, making them cheaper. In particular, $\mathrm{Hu}$ (2003) finds that large firms are particularly likely to hire young workers, which he ascribes to larger firms greater propensity to train. The management literature presents a variation on this theme, arguing that older workers accumulate not only specific training in the techniques of their firms but also in its "managerial culture." Once separated from their firm, such cultural knowledge actually makes them less valuable than new workers as they require retraining seen as more difficult than original training (Thomas and Ong 2002). Finally, searching for a good job match is costly (Hurd 1999: 37), and these costs are part of a part of a person's specific capital. Older workers changing jobs lose this capital, and cannot justify extensive search for the best match since the payback period is too short.

Whether Lazear-type deferred pay contracts, or specific training problems are more important in reducing hiring of older workers is a matter of debate. It is difficult to measure labour productivity. However, pioneering US work using supervisors' evaluations to measure productivity (Medoff and Abraham 1980, 1981) suggests that productivity growth within firms is less than earnings growth, as required by the Lazear contract. This result has since 
been replicated for Italy (Flabbi and Inchino 2001), and the Netherlands (Dohmen 2004).). In addition, Barth (1997) shows that in payment methods that do not require deferred pay contracts for motivation, such as piece rate schemes, there are negligible if any return to firm seniority. This result, combined with his evidence that the steepest wage profiles are not associated with the greatest training requirements, causes him to emphasize Lazear type contracts rather than human capital as the reason for increasing seniority wage profiles. Moreover, work by Neumark and Stock (1999) has found that US states with their own (early) age discrimination laws have steeper age earnings profile than other states. They take this remarkable result to imply that age discrimination laws reduce the risk of firms wrongfully discharging older workers, thereby lowering the contracting costs of long-term efficient contracts. This result implies that deferred pay contracts are in fact pervasive. In practice, of course, the hiring of older workers will be low both in jobs where monitoring difficulties require deferred pay contracts, and where much specific training is required.

\section{Policy-induced forces}

We now turn to Table 3, which considers policy factors affecting the market for older workers. Again, we will work through these entries in turn, taking first the supply side "tax force" and early retirement/disability policies.

The "tax force" is Gruber and Wise's (1999: 30) term for the burden of implicit taxes on continued work between ages 55 and 70 . We have referred to such implicit taxes above to explain different country retirement rates. Policies raising state retirement benefits, or lowering eligibility ages including early retirement/disability programmes increase implicit taxes on working. Thus, Gruber and Wise (2002: 24) estimate that delaying the age of benefit eligibility by 3 years increases the proportion of men 56-65 working by as much as $36 \%$ over the long run. In a similar vein, Duval (2003: 22) finds that changes in implicit tax rates and standard retirement ages explain about one-third of the trend decline in older males' participation in the OECD 1970-2000.

A further important policy is restricting employees from drawing incomes from state and/or company pensions while working, or not providing fair pension increases if a person decides to defer retirement and work on. An actuarially fair increase would ensure the annual pension payment increases by about 7\% for every year's deferment (Duval 2003: 23). In fact, as regards state pensions (Disney 2002), countries such as Portugal and Spain have made receipt conditional on withdrawal from work. France, for its part, while instituting a "pension reform" in 2003 (OECD 2005: 75), still requires workers to take a 6 month break after beginning their pension before returning to the same employer, and to face a limit on the combined income from pension and work. France, in fact historically relies much more on "early retirement", and will probably continue to do so. In the UK, at least it has been possible to combine the state pension with work since 1989, and in the US since 2000 when the earnings limit was removed.

However, as regards company/occupational pensions, in both the UK and US there are tax rules that make it difficult to combine work and pension, though the position is 
improving. Such rules have forced people to resign from their main work, and then seek parttime work which, as we have shown above, is bound to be off-putting and often leads to abrupt retirement. In fact in the UK (DWP 2007: 8), it was not until the Finance Act of 2004 (in force on 5 April 2006), that the tax rules governing registered pension schemes permitted a person reaching normal minimum pension age (50 until 2010, 55 thereafter) to draw their pension and remain in their employer's service. The rationale for these rules appears to have been an "unreasonable fear" (Booth and Cooper 2003) that tax revenue would be lost, since contributions are tax deductible. However, in 2002 the Treasury (2002: 4) admitted that these rules were "outmoded", and the Government (DWP 2002: 8) said it is "determined to do more for those in employment who are prevented by tax rules from carrying on working". Still, it is up to the trustees of the various schemes themselves to make the change, and the process has been slow (Labour Research 2008: 28) due to worries about the effects of the new Age Discrimination Regulations (see below). At least policy is moving in the right direction.

In this respect, the UK may be ahead of the US where most pension plans cannot make payment to current employees until the plan's normal retirement age of 65 . Moreover, suspension rules in the US mean that those working beyond normal retirement age with their career employer usually cannot access retirement benefits (see Penner 2002 on both points).

The final policy entry in the supply-side column is union power. Recent work by Bertola, Blau and Kahn (2007) using a 17 country OECD dataset with a long time period 1960-1996, has found strong adverse effects of union power for 55+ workers' participation. In this work they measure power by union membership, collective bargaining coverage, and also bargaining coordination. All have negative effects on older workers' participation - and on younger workers - while leaving prime age workers unaffected. These results hold constant major features of country pension systems such as the retirement age, and pension replacement rate, as well as the unemployment rate, EPL, total tax wedge, and the unemployment and disability replacement rates in an equation reminiscent of Nickell's (1997) famous paper on labour supply also using a (smaller) OECD country dataset. They explain the results in terms of unions rationally pricing out of the workforce those groups which have good non-employment alternatives like subsidised retirement. According to these results, our comparison above (Figure 4) of the UK with France, chimes in with the high bargaining coverage in France helping explain its low participation.

Interestingly, there is no evidence in Bertola, Blau and Kahn's (2007) results that bargaining coordination reduces the adverse effects of union power. Nickell's (1997) earlier results had found such a reduction which occurred, he argued, because coordination prevented leapfrogging union wage claims generating inflationary pressure. This result led Nickel and Layard (1999: 3067) to claim that a 100\% unionised and collective agreement country, which was also fully coordinated had no worse a performance than a noncoordinated, zero-union and zero-coverage country. Thus, "responsible" unionism was possible. No such optimistic conclusion can be made on the basis of the Bertola, Blau and Kahn (2007) study. Thus, the policy conclusion for the market for older workers is that laws reducing union power should be maintained to increase labour force participation among the old. 
Moving to the demand-side column, we begin with EPL. Strict EPL is likely to reduce the hiring rate of older workers. In general, EPL reduces hiring because personnel offices have to be more "choosy" - which is why we classify EPL as a demand side factor. Such a reduction in hiring will be matched by a reduction in firing, and so the unemployment rate need not increase, but unemployment duration always will (Siebert, 2005). People will spend longer looking for work, and this means particularly the older workers who are a classic outsider group without a relevant track record, and therefore more of a risk than prime-age workers. Daniel and Siebert's (2005) study of matched plants in various OECD countries confirms this prediction. The same pattern is found in Bertola, Blau and Kahn's (2007) results. The OECD (2006: Table 3.3) study notes that strict EPL in France, such as the Delalande contribution noted above, has been linked to substantial use of early retirement schemes. The policy conclusion is therefore plain: widening up the labour market for older workers requires avoiding strict EPL.

Finally, let us consider age discrimination law, which in fact is a double-edged sword because it is a form of EPL. The UK's age discrimination law is contained in the Employment Equality (Age) Regulations (UK, 2006), brought in to give effect to the EU's framework equal treatment directive (EU, 2000). Old workers are obviously different in many ways from young, so age "discrimination" is vital for business. The age of the worker influences the time horizon of any human capital (training) investment and also the influence of deferring compensation on effort. Hence, the Directive had the unenviable task of requiring equal treatment for the unequal, which it attempted to solve via Article 6 which allows differences of treatment on grounds of age, so long as these can be "objectively and reasonably justified", which is a lawyer's paradise.

Thus, the Age Regulations ${ }^{3}$ need a long list of situations when "discrimination" is allowed e.g. for seniority pay, or for redundancy pay, and have created uncertainty. Certainly, just as in the US case (Neumark and Stock 1999), since hiring discrimination is more difficult to prove (e.g., for lack of comparators), most cases are likely to revolve around dismissal. With heightened risk of litigation when dismissed or with the implicit decision to retain older workers regardless of productivity, we can therefore expect older workers to find it more difficult to be hired. US results (Lahey 2006) indeed find that older workers in states with age discrimination laws work around 2 weeks less a year, and have $13 \%$ retired compared to $11 \%$ in states without the laws.

The Age Regulations have also established a "default retirement age" of 65 which has caused uncertainty and might interrupt the beneficial movement towards flexible retirement we have observed earlier. The default retirement age reduces the chance that employers will be sued for "unfair dismissal" for not objectively justifying why they ask particular workers to retire. However, it has caused uncertainty among trustees of pension schemes who are responsible for changing the rules of their schemes to allow employees to stay on and draw a pension. Admittedly there has been some movement, with Sainsburys, for example (Labour

\footnotetext{
${ }^{3}$ Our favourite is Rule 30 on the Exception for Retirement, which is said to apply to employees including "a relevant member of the House of Commons staff, and a relevant member of the House of Lords staff". At least they have remembered the important people.
} 
Research 2008: 29), now enabling staff to remain in their scheme, accrue benefits and be employed until 75. But the Department of Work and Pensions (2007) notes "confusion" in the application of the Age regulations and their application to flexible retirement. In sum, the default mandatory retirement idea probably does not much help to employers in their battle with the age regulations, and consequently harms the market for older workers in addition, as suggested in our opening quote.

\section{Conclusions}

We began by asking why retirement is generally so abrupt. The short answer is that in most countries it has historically been difficult to work and receive a pension. UK pension rules, just as in other countries, discouraged on-going relationships with existing employers, despite the fact that those employers had already paid the fixed costs associated with hiring and training and it was to those firms that the workers were most valuable. The alternative of work in another business will always be poorly paid because of the hiring and training costs. Hence many choose to retire. However, things have changed for the better at least in the UK. The challenge for the UK will be to continue to pursue the policy revisions begun with the Finance Act of 2004 that remove tax penalties from pensioners who choose to work.

Our presumption is that policy interventions should encourage older workers who wish to continue working to remain in the labour force. Disability laws that lead to early retirement via public pensions create a high implicit tax on working and should be reformed. As made clear, these implicit taxes are high in France and remarkably low in Japan. Strict EPL and high union collective agreement coverage also have a role to play in France's poor performance. The Japanese case is illustrative as it combines mandatory retirement at 60 with a pension, plus continuation of work full- or part-time through a series of temporary contracts. Critically, these temporary contracts are easier to structure as Japan does not have strict EPL or an age discrimination law.

We also asked at the beginning whether "age discrimination" laws are likely to help the market for older workers. Our answer here is no. As we have noted, older workers are obviously different from younger, so discrimination is vital for business. Indeed, there is US evidence that age discrimination laws lead to less hiring of older workers, which is to be expected, since such age laws are a form of EPL. The addition of the default mandatory retirement age of 65 in the UK regulations has made the situation worse, by preventing pension schemes developing to allow flexible retirement. Hopefully the mandatory retirement age will be lifted, and the confusion caused by unhelpful age discrimination laws will subside. It is then likely that in the long run in the UK the easing of constraints on older workers working will continue. 


\section{Table 1: Demand \& Supply Forces Causing Retirement}

\begin{tabular}{|c|c|}
\hline Supply-side: & Demand-side: \\
\hline $\begin{array}{l}\text { (Factors reducing older worker labour } \\
\text { supplies) }\end{array}$ & $\begin{array}{c}\text { (Factors reducing firms' demand for } \\
\text { older workers) }\end{array}$ \\
\hline - Health problems & $\begin{array}{l}\text { Fixed costs of hiring and training: } \\
\text { weigh on older hires more due to } \\
\text { their shorter expected tenure (Hurd } \\
\text { 1996) }\end{array}$ \\
\hline $\begin{array}{l}\text { - Increasing tastes for leisure with age } \\
\text { (Zabalza et al. 1980, Blau \& } \\
\text { Shvydko 2007) }\end{array}$ & $\begin{array}{l}\text { Team work: } \\
\text { cannot accommodate shorter hours } \\
\text { required by older workers (Hurd } \\
\text { 1996, Delsen 1996) }\end{array}$ \\
\hline \multirow[t]{2}{*}{$\begin{array}{l}\text { - Older workers less adaptable } \\
\text { (O’Mahoney \& Peng 2008) }\end{array}$} & $\begin{array}{l}\text { Deferred pay incentive schemes: } \\
\text { linked to mandatory retirement } \\
\text { (Lazear 1980) and low hiring of } \\
\text { older workers (Hutchens 1986, } \\
\text { Daniel \& Heywood 2007) }\end{array}$ \\
\hline & $\begin{array}{l}\text { Specific training: } \\
\text { less profitable for older workers }(\mathrm{Hu} \text {, } \\
\text { 2003) }\end{array}$ \\
\hline
\end{tabular}


Table 2: Empirical Studies on Deferred Compensation and the Age of Hires

\begin{tabular}{|c|c|c|c|c|}
\hline & $\begin{array}{l}\text { Country } \\
\text { of Study }\end{array}$ & Data Source & $\begin{array}{l}\text { Dependent } \\
\text { Variable(s) }\end{array}$ & Key Results \\
\hline $\begin{array}{l}\text { Hutchens } \\
\text { (1986) }\end{array}$ & $\begin{array}{l}\text { United } \\
\text { States }\end{array}$ & $\begin{array}{l}\text { Labour Force } \\
\text { Survey (CPS) } \\
\text { occupation/indus } \\
\text { try cells }\end{array}$ & $\begin{array}{l}\text { Pensions; } \\
\text { Mandatory } \\
\text { retirement; } \\
\text { Tenure }\end{array}$ & $\begin{array}{l}\text { Opportunity Index* is a } \\
\text { negative determinant of each } \\
\text { measure of back-loading }\end{array}$ \\
\hline $\begin{array}{l}\text { Scott et } \\
\text { al. }(1996)\end{array}$ & $\begin{array}{l}\text { United } \\
\text { States }\end{array}$ & $\begin{array}{l}\text { Original Survey } \\
\text { of Firms; } \\
\text { Labour Force } \\
\text { Survey (CPS) }\end{array}$ & $\begin{array}{l}\text { Share of Older } \\
\text { Hires; } \\
\text { Whether or not } \\
\text { a new hire is } \\
\text { old }\end{array}$ & $\begin{array}{l}\text { Firm contribution to health } \\
\text { insurance reduces share; } \\
\text { Provision of health insurance } \\
\text { reduces probability of older } \\
\text { hires }\end{array}$ \\
\hline $\begin{array}{l}\text { Hirsch et } \\
\text { al. (2000) }\end{array}$ & $\begin{array}{l}\text { United } \\
\text { States }\end{array}$ & $\begin{array}{l}\text { Labour Force } \\
\text { Survey (CPS) }\end{array}$ & $\begin{array}{l}\text { Opportunity } \\
\text { Index }\end{array}$ & $\begin{array}{l}\text { Wage tilt within the } \\
\text { occupation and pension } \\
\text { provision each reduce the } \\
\text { index }\end{array}$ \\
\hline $\begin{array}{l}\mathrm{Hu} \\
(2003)\end{array}$ & $\begin{array}{l}\text { United } \\
\text { States }\end{array}$ & $\begin{array}{l}\text { Labour Force } \\
\text { Survey (CPS) }\end{array}$ & Age at hire & $\begin{array}{l}\text { Pattern of earnings at age of } \\
\text { hire and by firm size } \\
\text { presumed inconsistent with a } \\
\text { role for deferred } \\
\text { compensation }\end{array}$ \\
\hline $\begin{array}{l}\text { Daniel } \\
\text { and } \\
\text { Heywood } \\
(2007)\end{array}$ & $\begin{array}{l}\text { United } \\
\text { Kingdom }\end{array}$ & $\begin{array}{l}1998 \text { Workplace } \\
\text { Employment } \\
\text { Relations Survey }\end{array}$ & $\begin{array}{l}\text { Share of Older } \\
\text { Hires }\end{array}$ & $\begin{array}{l}\text { Pension provision, wage tilt } \\
\text { and internal recruitment each } \\
\text { reduce the share }\end{array}$ \\
\hline $\begin{array}{l}\text { Adams } \\
\text { and } \\
\text { Heywood } \\
(2007)\end{array}$ & Australia & $\begin{array}{l}1996 \text { Australian } \\
\text { Workplace } \\
\text { Industrial } \\
\text { Relations Survey }\end{array}$ & Age at hire & $\begin{array}{l}\text { Wage tilt within establishment } \\
\text { reduces age at hire }\end{array}$ \\
\hline $\begin{array}{l}\text { Heywood } \\
\text { et al. } \\
(2008)\end{array}$ & Germany & $\begin{array}{l}2002 \text { Hanover } \\
\text { Firm Panel }\end{array}$ & $\begin{array}{l}\text { Managerial } \\
\text { willingness to } \\
\text { hire older } \\
\text { workers }\end{array}$ & $\begin{array}{l}\text { Private pensions and deferred } \\
\text { share ownership both reduce } \\
\text { willingness }\end{array}$ \\
\hline $\begin{array}{l}\text { Heywood } \\
\text { et al. } \\
(1999)\end{array}$ & $\begin{array}{l}\text { Hong } \\
\text { Kong }\end{array}$ & $\begin{array}{l}\text { Original } \\
\text { Establishment } \\
\text { Survey }\end{array}$ & $\begin{array}{l}\text { Managerial } \\
\text { willingness to } \\
\text { hire older } \\
\text { workers }\end{array}$ & $\begin{array}{l}\text { Pension provision and average } \\
\text { tenure each reduce both the } \\
\text { share and the willingness }\end{array}$ \\
\hline
\end{tabular}

Note: Central results only provided, but note that each study has wide variations in measurement, specification and results. Hutchen's (1986) opportunity index is the share of older worker hires as a proportion of the share of old workers, calculated by occupation and industry. Modern research calculates the index using firm data. 
- The "tax force": high implicit taxes on continued work once social security eligibility age is reached, plus early eligibility (Gruber \& Wise 1999, Duval 2003))

- Rules against working while receiving a pension (Treasury 2002)

- Union power: unfavourable for older workers, e.g. seniority wages set older worker wages high (Bertola et al. 2007)
- Strict EPL:

means older hires shunned (Daniel \& Siebert 2005, OECD 2006)

- Age discrimination legislation: - might act as EPL (Adams 2004, Lahey 2006; but see Neumark and Stock 1999)

- might reinforce mandatory retirement (UK Age Regulations 2006) 


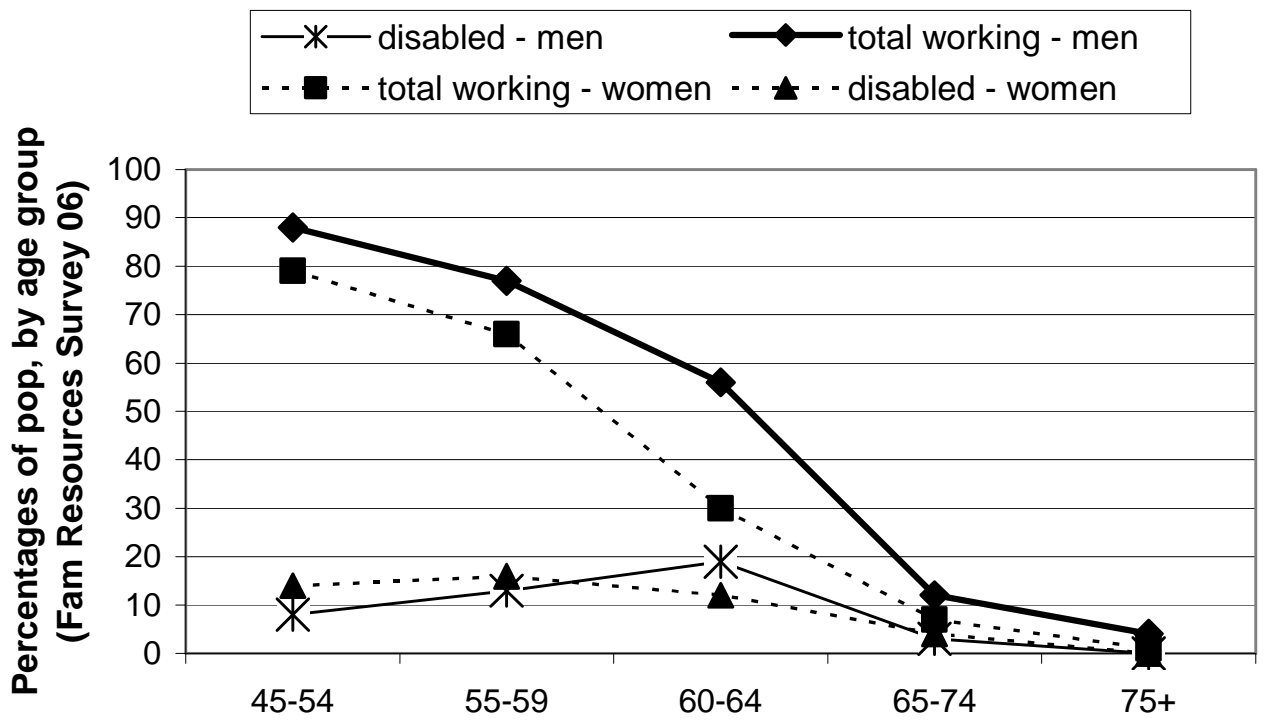

Figure 1: Labourforce participation and disability by age group, UK 2006

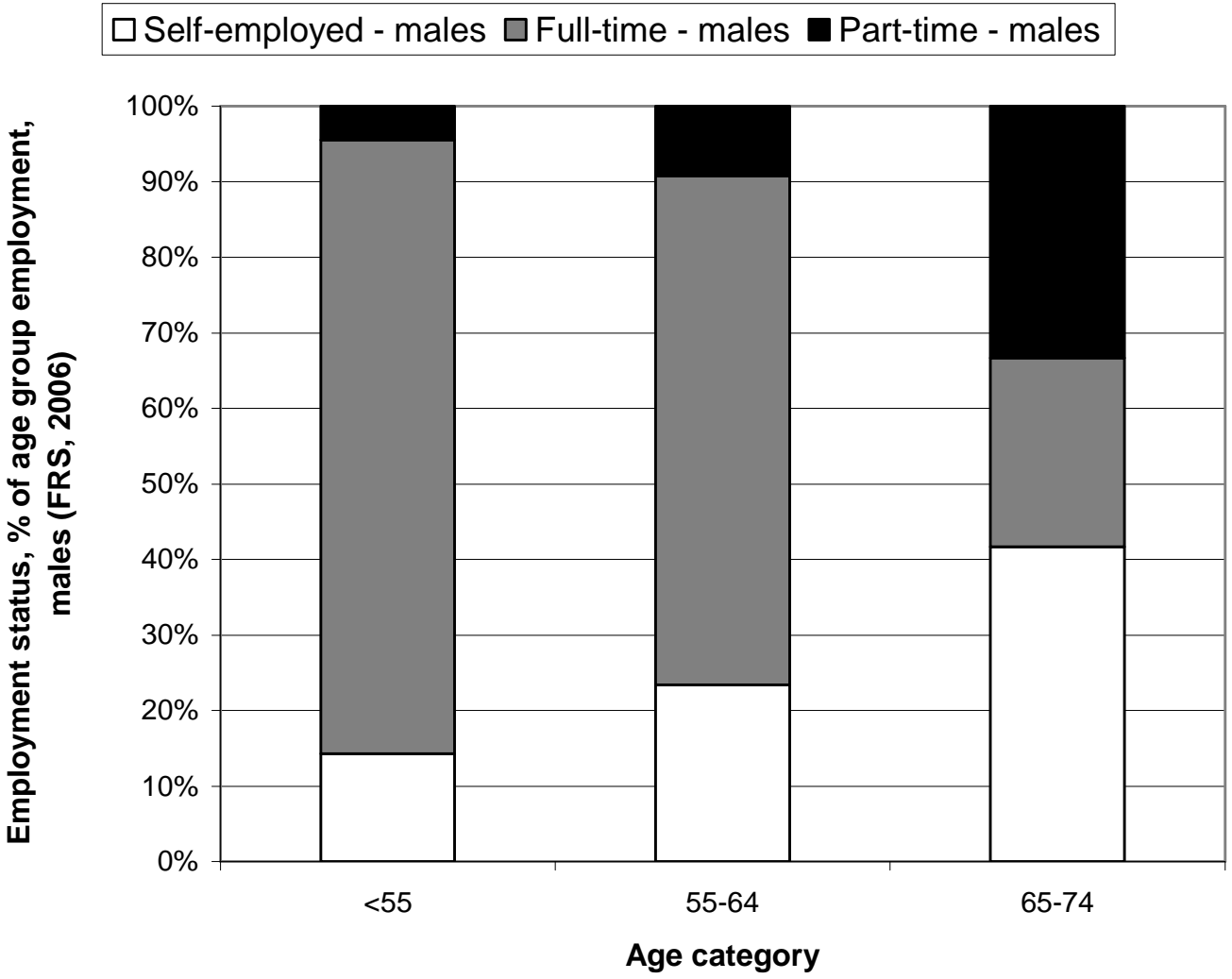

Figure 2: Self-, part- and full-time employment for older men, UK 2006 


\section{$\square$ Self-employment - Females $\square$ Full-time - females $\square$ Part-time - females}

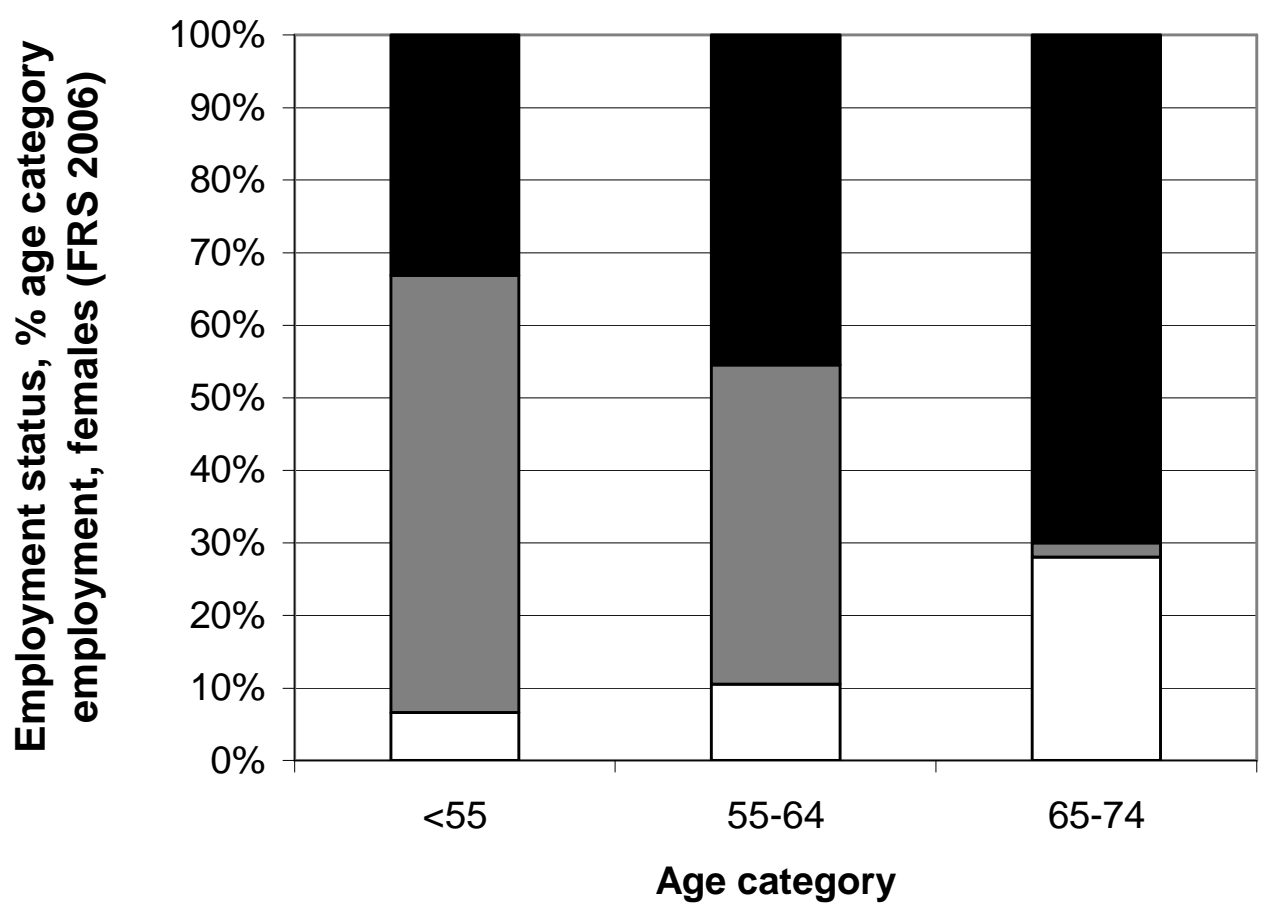

Figure 3: Self-, part- and full-time employment for older women, UK 2006

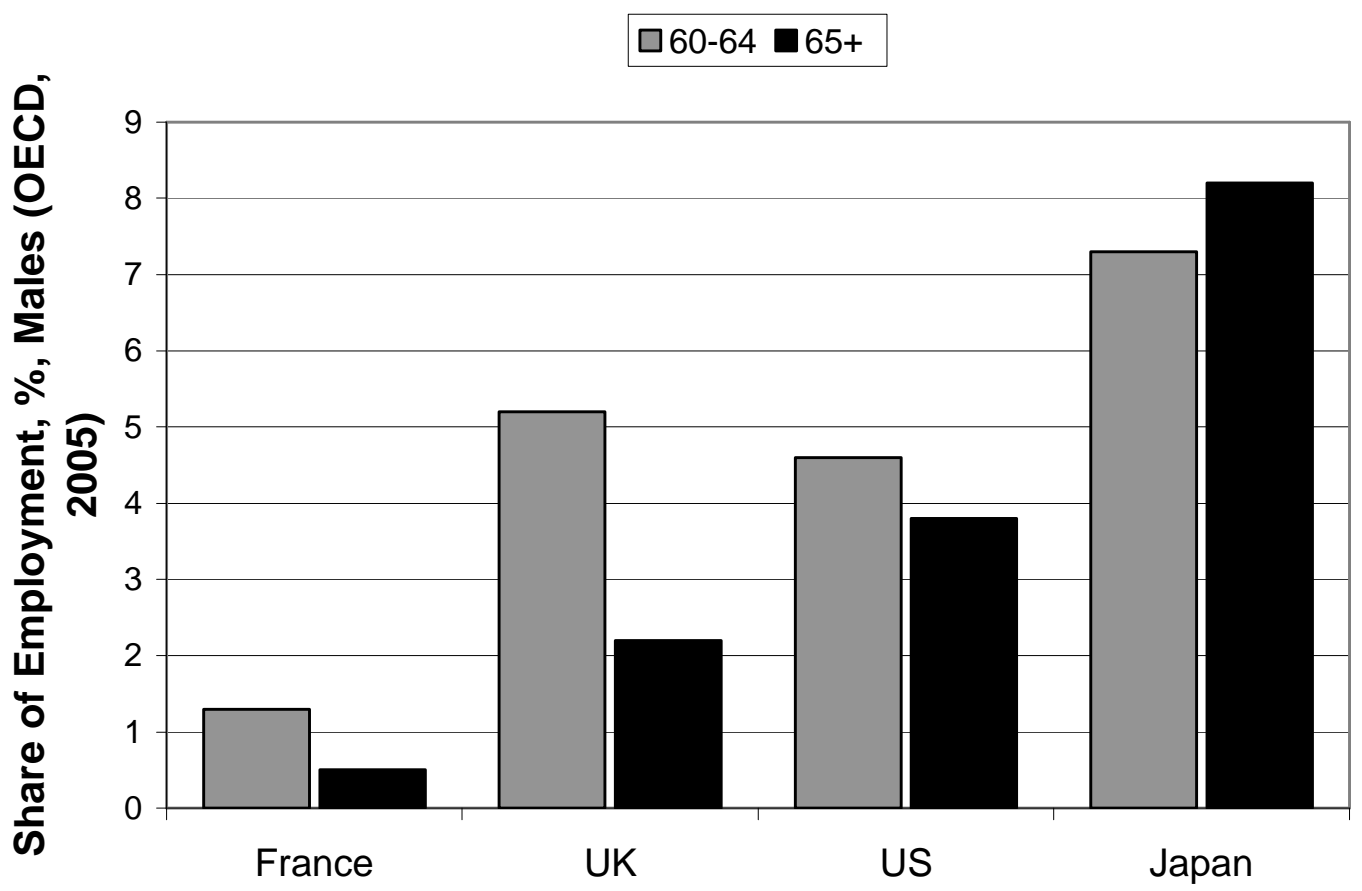

(Note: Shares for female workers are similar)

Figure 4: Share of male older workers in total employment by country, 2005 


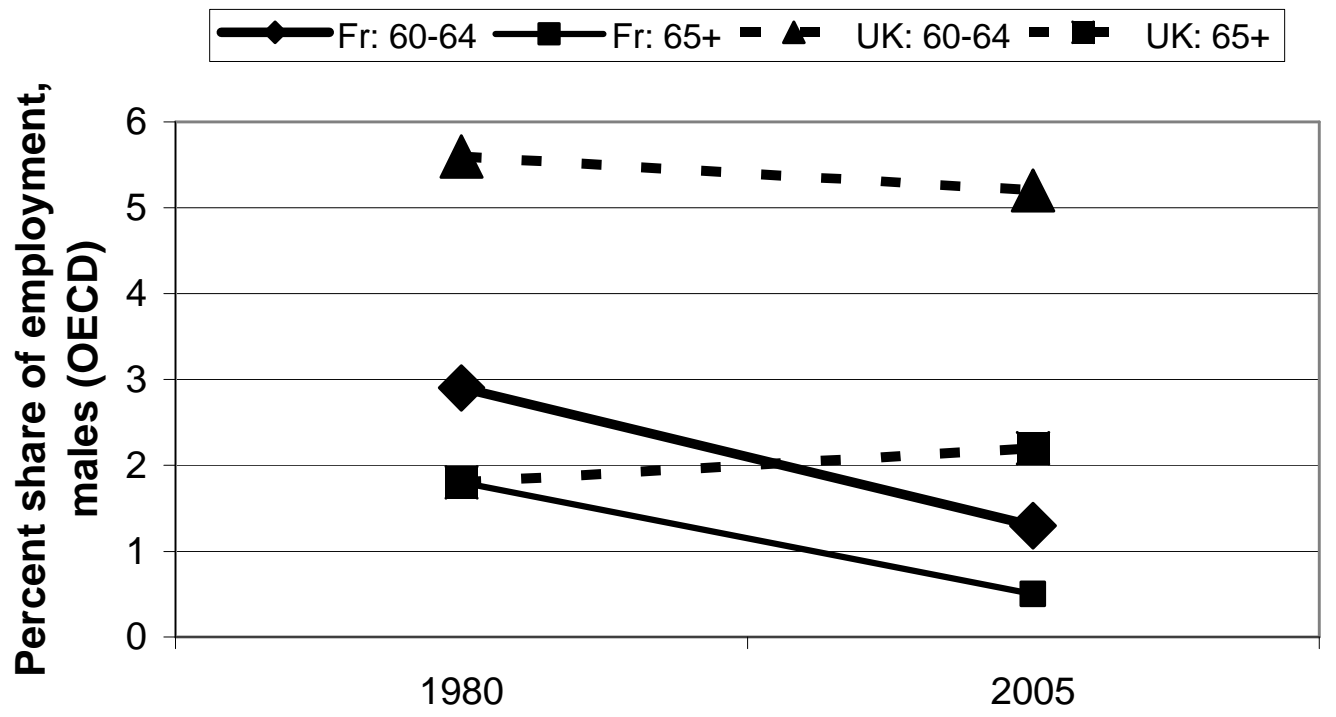

Figure 5: Change in labourforce participation of older male workers in the UK and France

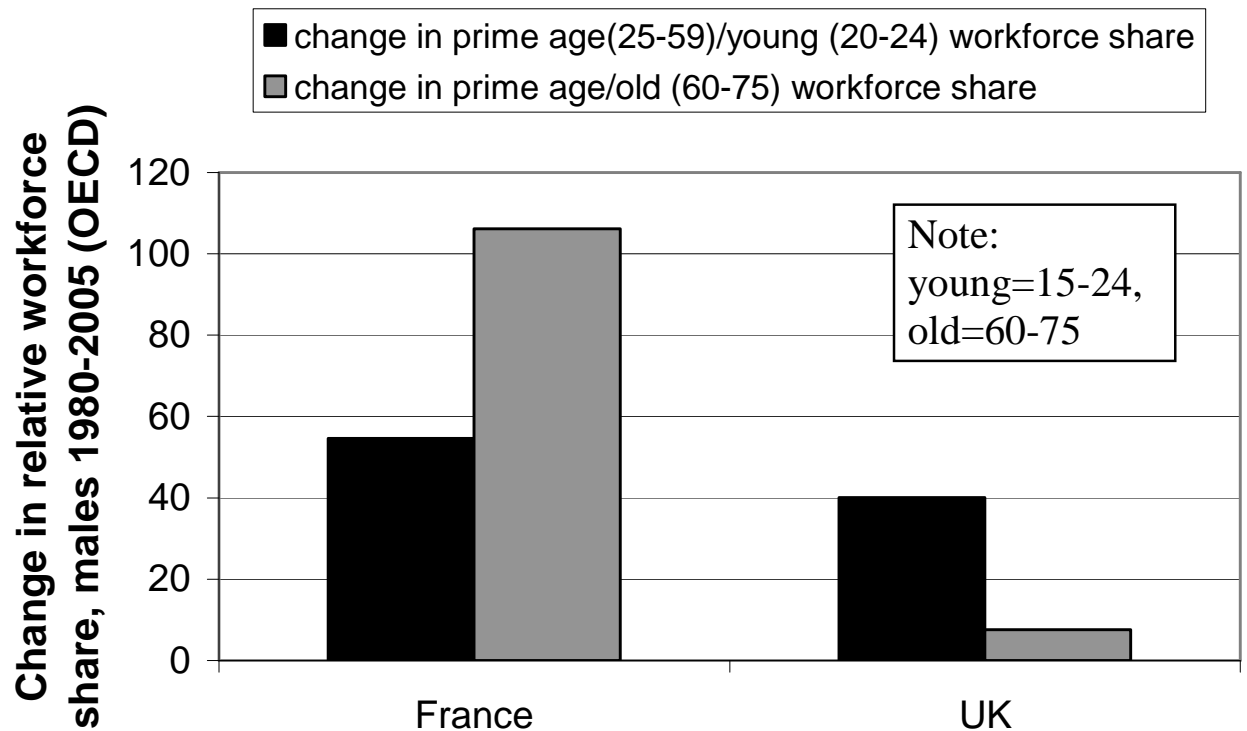

Figure 6: Changes in labourforce participation of young (20-24) and old (60-75) male workers relative to prime age, UK and France 


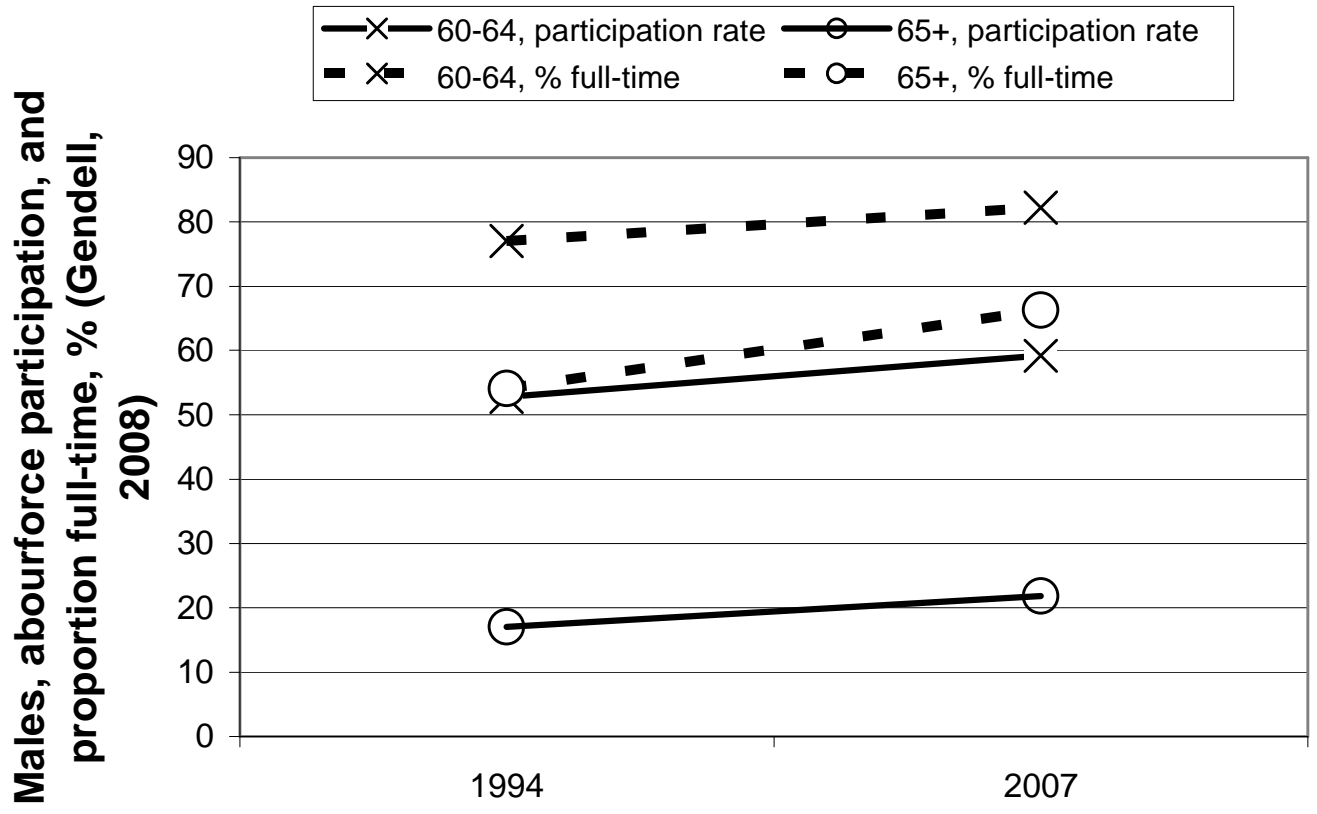

(Note: Trends for female workers are similar)

Figure 7: Changes in labourforce participation of older men, USA 1994-2007 


\section{References}

Adams, Scott. (2002). "Passed Over For Promotion Because of Age: An Empirical Analysis of the Consequences," Journal of Labor Research, Vol. 23, 447-461.

Adams S (2004). "Age Discrimination Legislation and the Employment of Older Workers". Labour Economics, 11: 219-241.

Aubert, P., E. Caroli and M. Rogers (2006) "New Technologies, Organization and Age: Firm Level Evidence," Economic Journal 116, 509: F73 - F93.

Barth, E. "Firm Specific Seniority and Wages," Journal of Labor Economics 15, 3: 495 - 506.

Bertola G, F Blau and L Kahn (2007). "Labour market Institutions and Demographic Employment patterns", Journal of Population Economics, 20: 833-867.

Blanchet D and L-P Pele (1999). "Social Security and Retirement in France" in Gruber J and D Wise (eds.), Social Security and Retirement around the World. Chicago: University of Chicago Press.

Booth P and D Cooper (2003). "Simplifying the Taxation of Pensions". Economic Affairs, 23, 3: 46-52.

Blau D and T Shvydko (2007). "Labor Market Rigidities and the Employment Behaviour of Older workers”. IZA Discussion paper 2996, Bonn: Institute for the Study of Labour.

Daniel, K. and J.S. Heywood. (2007). "The Determinants of Hiring Older Workers: UK Evidence," Labour Economics, 14: 35-51.

Daniel K and W S Siebert (2005). "Does Employment Protection Reduce the Demand for Unskilled Labour?", International Economic Journal, 19: 1-26.

Delsen, L (1996). "Gradual retirement: Lessons from Nordic Countries and The Netherlands". European Journal of Industrial Relations, 2: 55-67.

Disney R (1996). Can We Afford to Grow Older? Cambridge, Mass.: The MIT Press.

Disney R and S Smith (2002). "The Labour Supply Effect of the Abolition of the Earnings Rule for Older Workers in the UK”, Economic Journal, 112 (March): C136-52.

Dohmen, T. (2004). "Performance, Seniority, and Wages: Formal Salary Systems and Individual Earnings Profiles," Labour Economics 11: 741 - 63.

Duval, R. (2003). "The Retirement Effects of Old-Age Pension and Early Retirement Schemes in OECD Countries," OECD Economics Department Working Papers, No. 370.

DWP (2002). Simplicity, Security and Choice: Working and Saving for Retirement. London: Department for Work and Pension, CM 5677.

DWP (2007). Flexible Retirement and Pension Provision, October. London: Department for Work and Pensions.

EU (2000). Coucil Directive 2000/78/EC of 27 November 2000, establishing a general framework for equal treatment in employment and occupation, Official Journal of the European Communities, L303/16.

Flabbi, Lucca and Andrea Ichino. 2001. "Productivity, Seniority and Wages: new Evidence from Personnel Data," Labour Economics 8: 359 -87.

FRS (2006). Family Resources Survey 2006-07. London: department of Work and Pensions.

Funk L (2002). Employment Opportunities for Older Workers: A Comparison of Selected OECD Countries. CESifo DICE Report 2.

Gendell, M. (2008). "Older Workers: Increasing their Labor Force participation and Hours of Work," Monthly Labor Review, Vol. 131, 41 - 54. 
Goldin, C. (1986). "Monitoring Costs and Segregation by Sex: A Historical Analysis." Journal of Labor Economics, Vol. 4, 1 - 27

Gruber J and D Wise (1999). "Introduction and Summary" in Gruber J and D Wise (eds.), Social Security and Retirement around the World. Chicago: University of Chicago Press.

Heywood, J.S., L.S. Ho and X. Wei. (1999). "The Determinants of Hiring Older Workers: Evidence from Hong Kong," Industrial and Labor Relations Review, Vol. 52, $444-59$.

Heywood, J.S., U. Jirjahn and G. Tesertsvadze (2008a). "Hiring Older Workers and Employing Older Workers: German Evidence," Journal of Population Economics, Forthcoming.

Hirsh, B.T., D.A. Macpherson and M.A. Hardy. 2000. "Occupational Age Structure and Access for Older Workers," Industrial and Labor Relations Review, Vol. $53,401-418$.

Ho, L.S., X. Wei and J.P. Voon. (2000). "Are Older Workers Disadvantaged in the Hong Kong Labor Market," Asian Economic Journal, Vol.14, 283 - 300.

Hurd M (1996). "The Effect of Labor Market Rigidities on the Labor Force Behaviour of Older Workers", in D Wise (ed.), Advances in the Economics of Aging. Chicago: The University of Chicago Press.

Hutchens, R. (1993). "Restricted Job Opportunities and the Older Worker," in Olivia Mitchell, ed., As the Workforce Ages. Ithaca , N.Y.: ILR Press, 81 - 102.

Hutchens, R. (1988). "Do Job Opportunities Decline with Age?" Industrial and Labor Relations Review, Vol. 42, 89 -99.

Hutchens, R. (1986). "Delayed Payment Contracts and a Firm's Propensity to Hire Older Workers," Journal of Labor Economics, Vol. 4, 439 - 57.

Labour Research (2008). Promoting Equality for Older Workers. London: Labour Research Department.

Lahey, Joanna. 2006. "State Age Protection Laws and the Age Discrimination in Employment Act," Working Paper 12048. Cambridge MA: National Bureau of Economic Research.

Lazear, Edward. (1981). "Agency, Earnings Profiles, Productivity and Hours Restrictions," American Economic Review, Vol. 71, 606 - 20.

Lazear, Edward. (1979). "Why is there Mandatory Retirement," Journal of Political Economy, Vol. 87, 1261 -84.

Mazolle, M.J. and G. Singh. (1999). "Older Workers' Adjustments to Plant Closures," Relations Industrielles - Industrial Relations, Vol. 54, 313 -36.

Meadows P (2005). Retirement Ages in the UK: A Review of the Literature. Employment relations Research Series 18: London; Department of Trade and Industry.

Medoff, James L. and Katherine G. Abraham. 1980. "Experience Performance and Earnings," Quarterly Journal of Economics 95: 703 - 736.

Medoff, James L. and Katherine G. Abraham. 1981. "Are those Paid More Really More Productive? The Case of Experience," Journal of Human Resources 16: 186 - 216.

Neumark, David and Wendy Stock. 1999. "Age Discrimination Laws and Labor Market Efficiency," Journal of Political Economy 107: 1081 - 1125.

Nickell S (1997). "Unemployment and Labour Market Rigidities: Europe versus North America". The Journal of Economic Perspectives, 11, 3: 55-74. 
Nickell S and R Layard (1999). "Labour Market Institutions and Economic Performance" in O Ashenfelter (ed.) Handbook of Labor Economics Vol 3c, Amsterdam: Elsevier: 3029-84.

OECD (2005). Ageing and Employment Policies - France. Paris; Organisation for Economic Cooperation and Development.

OECD (2006). Live Longer, Work Harder - Ageing and Employment Policies. Paris; Organisation for Economic Cooperation and Development.

OECD (2008). Economic Policy Reforms - Going for Growth. Paris; Organisation for Economic Cooperation and Development.

Oi, Walter. (1962). "Labor as a Quasi-Fixed Factor," Journal of Political Economy, Vol. 70: $538-55$.

O'Mahony M and F Peng (2008). "Skill Bias, Age and Organisational Change”, EU KLEMS Working Paper 36.

Penner R, P Perun and E Steuerle (2002). "Legal and institutional impediments to partial and part-time retirement". Washington: Urban Institute.

Schirle T (2008). "Why have the Labour Force Participation Rates of Older Men Increased Since the Mind-1990s?". Journal of Labor Economics.

Scott, F., M. Berger and J. Garen. (1995). "Do Health Insurance and Pension Costs Reduce the Job Opportunities of Older Workers?" Industrial and Labor Relations Review, 48: 775 - 91.

Seike A (1997). "Labor Market Implications of Social Security: Company Pension Plans, Public Pensions, and Retirement Behaviour of the Elderly in Japan", in M Hurd and N Yashiro (eds.) The Economic Effects of Aging in the United States and Japan, Chicago: The University of Chicago Press.

Siebert W S (2005). "Labour Market Regulation; Some Comparative Lessons". Economic Affairs, 25, 3: 3-10.

The Times (2008). "Setback in Battle against Compulsory Retirement Age", Francis Gibb, The Times, 24 September.

Treasury (2002). Simplifying the taxation of Pensions: Increasing choice and Flexibility for All (December). London: HM Treasury.

UK (2006). The Employment Equality (Age) Regulations 2006. Statutory Instrument 2006 No.1031, London: HMSO.

Watson World Wide (2004). Phased Retirement: Aligning Employer Programs with Worker Preferences (2004 Survey Report): Washington DC.

Yahsiro N and T Oshio (1999). "Social Security and Retirement in Japan" in Gruber J and D Wise (eds.), Social Security and Retirement around the World. Chicago: The University of Chicago Press.

Zabalza A, C Pissarides and M Barton (1980). "Social Security and the Choice between Full-Time Work, Part-time Work and Retirement". Journal of Public Economics, 14: 245-276. 


\section{APPENDIX ON DEFERRED PAY}

(.Refer to Table 2)

Hutchens (1986) shows that a constructed index of hiring opportunity is negatively associated with the extent of back-loaded compensation. The index is computed for specific occupation and industry cells in the US. It is the fraction of all hires who are old divided by the fraction of all the employed who are old:

\section{$\mathrm{I}(\mathrm{i}, \mathrm{j})=(\%$ of recently hired workers in industry $\mathrm{i}$ and occupation $\mathrm{j}$ over age $\mathrm{k}) /$ ( $\%$ of all employed workers in industry $\mathrm{i}$ and occupation $\mathrm{j}$ over age $\mathrm{k}$ )}

The values of this index are then attached to aggregated individual data from the National Longitudinal Survey using occupation and industry codes. The index is an independent variable that measures the opportunity for older workers (Hutchens set $\mathrm{k}$ at age 55) and it correlates negatively with years of tenure, having a pension and mandatory retirement. These three measures indicate delayed compensation. The use of aggregate industry and occupation cells raises issues of errors-in-variables that Hutchens recognizes: "Although firm level data would be ideal for this purpose, the requisite data do not exist" (Hutchens 1986: 451).

Scott et al. (1995) emphasize that health insurance in the US has a strong element of delayed compensation because federal tax and anti-discrimination laws prohibit firms from adjusting wages of older workers to reflect the firm's additional costs. ${ }^{4}$ Thus, they present evidence from a survey of US firms showing a strong negative association between the employer contribution to health insurance and the share of hiring accounted for by older workers. Hirsch et al. (2000) match data from the US Current Population Survey with the Dictionary of Occupational Titles to examine the hiring opportunities of workers age 50 and older. They find reduced opportunities for older workers in occupations with steep wage profiles, pension benefits and computer usage (a proxy for skills). Adams (2002) uses data from the US Health and Retirement Study presenting evidence that firm preferences to promote younger workers may be part of a pattern of delayed compensation. Indeed, older workers in firms with such preferences have, if anything, greater attachment to their job. ${ }^{5}$ Adams argues that older individuals are already in "the reward phase" of their contract and are less likely to be motivated by promotions.

Heywood et al. (1999) use data from Hong Kong demonstrating that older workers face reduced hiring opportunity when the firm provides a pension, has a well developed internal labour market, has high average tenure and values seniority. This evidence on actual hiring patterns is confirmed by the hiring preferences of managers (age discrimination is not illegal in Hong Kong). These same indicators of delayed compensation were positively related to a managerial preference to avoid older hires. This evidence of the role of delayed compensation stands beside evidence that older workers were simultaneously less likely to be hired when the skills of the job were substantial or took considerable time to accumulate. Heywood et al. (2008) confirm that in Germany, also without age discrimination laws but considering them,

\footnotetext{
${ }^{4}$ Gruber (1994) challenged the view that firms cannot adjustment wages to reflect fringe benefits. He found that those workers most likely to use mandated maternity benefits have lower wages.

${ }^{5}$ Gruber (1994) challenged the view that firms cannot adjustment wages to reflect fringe benefits. He found that those workers most likely to use mandated maternity benefits have lower wages.
} 
managers report less willingness to hire older workers when their firm provides pensions and other back-loaded compensation. Mazerolle and Singh (1999) use Canadian data showing that workers above age 55 when hired following a plant closure are unlikely to have jobs with "career growth," a finding consistent with the role of deferred compensation within an internal labour market. Daniel and Heywood (2007) use establishment data from the United Kingdom revealing that indicators of deferred compensation, including the steepness of the wage profile, reduce the probability of the establishment hiring older workers. 